\title{
Earth Crust Evolution (From Precambrian to Recent): Introduction
}

\author{
Singh VK* \\ Department of Geology, Bundelkhand University, India \\ *Corresponding author: Singh VK, Department of Geology, Bundelkhand University, Jhansi, India
}

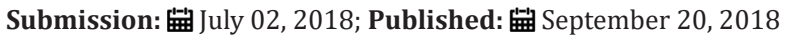

\section{Introduction}

The earth crustal growth since its formation still need in depth research which evolves a wide range of geological processes including plate tectonics and magmatic on which man life existing. Therefore, this special volume planned after organising three International Conferences on Precambrian Continental Growth and Tectonism, in 2005, 2009 and 2013 at the Institute of Earth Sciences of Bundelkhand University, Jhansi, India, for the vitality of interactive platforms which provide scholars with the much- needed opportunities for closer interaction and thought exchange. The proceedings of these conferences had incorporated the great ideas and achievements from scientists, acting as a valuable source for advance research [1-3]. This thematic issue contains 16 research articles on geodynamic evolution of earth, geomorphology, structural, petrologic, isotopic, tectonic, and geochemistry investigations related to the earth crust and its economic importance for society.

The first paper is by S.A. Svetov et al. discuss the key magmatic systems including the komatiite-basalt and andesite which play an important role in the Archean crust-forming processes, particularly in the accretion collision processes, probing from Karelian craton. The mafic rocks formed large allochthon complexes on the continental margin that resulted in the increasing of the continental crust thickness. Subduction of separate plates caused the formation of adakitic and bajaitic assemblages during its melting and basalt andesite - dacite- rhyolite and tonalite- trondhjemite-granodiorite complexes in the processes of mixing with mantle wedge.

S.B. Lobach-Zhuchenko et al. focus on $\mathrm{U}-\mathrm{Pb}$ and $\mathrm{Lu}-\mathrm{Hf}$ isotopic analyses on a zoned peridotite lens occurring in the orthogneisses of the Ukrainian shield which show evidence of magmatic origin of zircon. The $\varepsilon \mathrm{Hf}$ (2.8Ga) of zircon varies from -8.5 to -10.7 and indicates that the ultramafic melt contained an old component probably assimilated from the host orthogneiss.

N.B. Kuznetsov et al. discuss sources of Early Precambrian Ordovician terrigenous rocks of the Sol-Iletsk arch, East European platform, Russia after comprehensively U-Pb age, Hf-isotope and trace-elements studies. They found that the primary detrital zircons were most likely sourced from the crystalline complexes of the Late Proterozoic Volgo-Sarmatian and Taratash orogens and Archean
Volga-Uralia basement which is atypical for the southeastern part of the East European platform.

Goroshko MV et al., presents high-grade uranium-tantalumniobium ores occur in the Arbarastakh massif of alkaline ultrabasic rocks of Proterozoic age and estimated two types of metasomatic processes in the region. Slabunov AI and Singh VK reviews the Indian crustal evolution of Bundelkhand and Dharwar craton in Archean time and show that each of the cratons displays its own crust formation pattern.

M. V. Goroshko et al. presents high-grade uranium-tantalumniobium ores occur in the Arbarastakh massif of alkaline ultrabasic rocks of Proterozoic age and estimated two types of metasomatic processes in the region.

A.I. Slabunov and V.K. Singh reviews the Indian crustal evolution of Bundelkhand and Dharwar craton in Archean time and show that each of the cratons displays its own crust formation pattern.

A. Slabunov et al. established that compositional characteristics of the Ikauna intrusions are well-differentiated complex comprising dunite (serpentinite), pyroxenite, gabbro and gabbro-pegmatite rocks in Bundelkhand craton, India. The metagabbro are enriched by $\mathrm{Rb}$ and $\mathrm{Ba}$ and positive $\mathrm{Sr}$ and $\mathrm{Eu}$ anomalies, expected for the presence of cumulus plagioclase whereas metadunites and metapyroxenites show lower trace element abundances and negative $\mathrm{Sr}$ anomalies, related to fractional crystallization of plagioclase. These complexes have similar characteristic with the layered intrusions of the peridotite-gabbronorite complex of the Karelian craton.

B. Neupane and J. Zhao evaluates detrital zircon U-Pb dating of the Tansen basin foreland sedimentary formations from Central Nepal and indicates that the spectra with a common pattern of major age peaks clustered at $\sim 500-750 \mathrm{Ma}, 800-1200 \mathrm{Ma}, \sim 1830$ Ma and $\sim 2500$ Ma in the Himalaya.

Y. Singh present granite-pegmatite systems of the Bastar craton, India for host polymetallic $\mathrm{Nb}, \mathrm{Ta}, \mathrm{Sn}, \mathrm{Be}, \mathrm{Li}$, ore deposits, which are genetically related to various granitic bodies suggest a crustal origin. 
Shahnawaz et al., present mineral compositions of the MesoNeoproterozoic Sandstones from Chittorgarh, Rajasthan, India which have chief abundant of plutonic quartz originated mainly from granitic batholiths or granite-gneisses and the modal analysis suggested the product of multiple sources, including plutonic basement, sedimentary and metasedimentary rocks.

S.K. Devi and H. Thomas discusses petrography and geochemistry of gneissic rocks from central Rajasthan, India as they were coarse-grained, light colored exhibiting well augen gneissic characteristics alumina rich and high in potash content. These augen gneisses were found to be originated from granite to granodioritic igneous parentage of calc-alkaline composition in the tectonic setting of within plate granite.

A.R. Mir and S.H. Alvi report geochemical characteristics of the ultramafic dykes, Singhbhum craton, India, that they are picritic in nature and show arc related tectonic setting formed by subduction related basaltic rocks.

P.K. Singh explains Platinum Group of Metals occurrence in ultramafic and associated rocks from south part of Bundelkhand Craton, India and has good potential for a PGM deposit may be associated with plume/ superplume activity during crustal evolution of the craton.

V.K. Singh et al. point out that the low-grade banded iron bearing rocks are occurring around Babina, Mauranipur and Girar area in Bundelkhand craton, India may be potential source of iron. The BIF of the Kostomuksha greenstone belt of the Karelian craton is very similar to the BIF of the Mauranipur greenstone belt but without extreme Mn concentrations. This BIF was probably formed in a fore-arc basin supplied with terrigenous material and indicate that the composition of BIF is a sensitive indicator of geodynamic settings.

Mishra S et al. discuss geodynamic settings of Neoarchean granodiorite-granite series rocks which suggest subduction tectonic setting formed in active continental edge where oceanic crust subducted under continental block by accretion-collision system. The plagioclase-orthoclase granite produced due to anhydrous partial melting of the Paleo-Mesoarchean TTG or mafic crustal materials in an extensional regime after post-accretionary processes.

Kaplay RD et al. reported an outline of the morphometric and structural studies from western margin of East Dharwar craton, India, have strike-slip fault characteristics and the elongation ratio of the sub-basins suggests tectonically active.

D.C. Banerji et al. discuss about Sausar Stratigraphy in central India on studies of contact metamorphic assemblages in calcareous metasediments and their ubiquitous presence, as lenses, along with the presence of numerous smaller metacarbonates patches. These occurrences within the surrounding gneiss further strengthens the possibility of the biotite gneiss being intrusive within the calcareous rocks of Sausar Group.

\section{Acknowledgment}

I gratefully acknowledge Ellen Moore and Tara Minnillo for managing Archaeology \& Anthropology: Open Access publication and providing the opportunity to publish this thematic issue and for helping in various ways through the editing work. I express my sincere thanks to Prof. M.M. Singh, Head of the Department of Geology, Bundelkhand University, Jhansi, India for providing the necessary facilities to complete this thematic issue and all contributors in this issue and very well-wishers for their help in many ways. This special issue will be useful for geologists, academics, research scholars and also for those interested in problems of the earth crust evolution history.

\section{References}

1. Chandra R, Singh VK, Sivaji Ch, Piper JDA (2007) Precambrian continental growth and tectonism: Introduction. Gondwana Research 12(3): 199-201.

2. Singh VK, Chandra R (2011) Precambrian continental growth and tectonism: Introduction. In: Singh VK, Chandra R (Eds.), Proceeding of the $2^{\text {nd }}$ International conference Precambrian Continental Growth and Tectonism, Angel publication, India, pp. 1-2.

3. Singh VK, Chandra R, Basu AR, Verma SP, Biswal TK (2015) Precambrian crustal growth and tectonics: Introduction. International Geology Review 57(11-12): v-viii.
Creative Commons Attribution 4.0

International License

For possible submissions Click Here

\section{Submit Article}

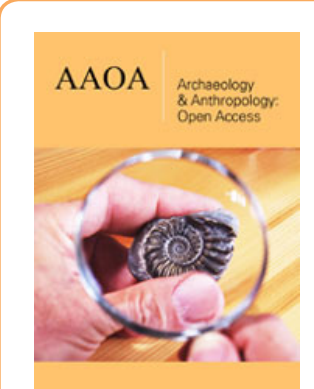

\section{Archaeology \& Anthropology: Open Access}

\section{Benefits of Publishing with us}

- High-level peer review and editorial services

- Freely accessible online immediately upon publication

- Authors retain the copyright to their work

- Licensing it under a Creative Commons license

- Visibility through different online platforms 